\title{
ЛІТЕРАТУРНА НОРМА У ПРОФЕСІЙНОМУ СПІЛКУВАННІ МЕДИЧНИХ ПРАЦІВНИКІВ
}

\author{
В. І. Зевако, А. М. Пришляк, В. Я. Юкало \\ ДВНЗ “Тернопільський державний медичний університет \\ імені І. Я. Горбачевського МОЗ Украӥни”
}

\section{LITERARY NORMS IN PROFESSIONAL COMMUNICATION OF MEDICAL WORKERS}

\author{
V. I. Zevako, A. M. Pryshlyak, V. Ya. Yukalo \\ SHEI "Ternopil State Medical University by I. Ya. Horbachevsky of MPH of Ukraine"
}

\begin{abstract}
У статті проаналізовано особливості інтер- та інтрапрофесійного спілкування як складових фахової комунікації. Визначено роль літературної норми й досліджено реалізацію акцентологічних та лексичних норм у спілкуванні медичних працівників.
\end{abstract}

The article analyzed specialties of inter- and intraprofessional communication as a part of communication of specialists. It is defined the role of literary norm and explored realization of accentological and lexical norms in communication of medical workers.

Вступ. Окремі аспекти реалізації літературної норми завжди перебували у сфері вивчення різних галузей лінгвістики. Останніми роками активізувався комунікативний підхід до мови, який означає вивчення умов реальної комунікації, впливу інтра-та екстралінгвальних чинників на тип спілкування, обставини комунікації, взаємостосунки між численними висловлюваннями, мовцем і адресатом. Він полягає у вивченні мови з погляду відповідності її структури до завдань спілкування.

Комунікативний аспект актуальний і для вивчення професійного мовлення медичних працівників. У фаховій діяльності лікар повинен володіти культурою конструктивного діалогу, вміти сприймати, відтворювати та готувати фахові тексти, знати прийоми написання і виголошення публічного виступу, вміти вести, підтримувати ділову розмову. Для цього він має вміло реалізувати у своєму мовленні різноманітні літературні норми.

Новизна роботи полягає в комплексному підході до вивчення реалізації літературних норм у професійному спілкуванні медичних працівників.

Мета дослідження - вивчення реалізації літературних норм у різних формах професійної мови та

( В. І. Зевако, А. М. Пришляк, В. Я. Юкало впровадження кодифікованих засобів у спілкування медичних працівників.

Основна частина. У професійній комунікації на основі психологічних і соціальних особливостей статусу партнерів - відправника мови і адресата - дослідники виділяють як самостійні інтерпрофесійну i інтрапрофесійну комунікації. Інтерпрофесійна комунікація складається з мовних актів, в яких професійні ролі комунікантів не збігаються. Характерним прикладом у цьому випадку є спілкування "лікар пацієнт". Інтрапрофесійна комунікація здійснюється всередині певної соціально-професійної спільноти.

Інтрапрофесійна комунікація включає, з одного боку, однодисциплінарні (“психіатр-психіатр”, “окулістокуліст” тощо) та різнодисциплінарні гілки (модель “лікар-офтальмолог-лікар-патологоанатом”, “лікар - провізор", “лікар-рентгенолог - лікар-онколог” тощо), з іншого боку, передбачає спілкування між спеціалістами різної кваліфікації (модель “лікар медсестра", “лікар - фельдшер”, “лікар-гінеколог акушерка", “лікар - санітар" тощо), міжперсональну (розмова медичних працівників, усна інструкція з експлуатації медичного приладу) і публічну комунікацію (лекція на медичну тему).

Інтерпрофесійна комунікація лікаря може відбуватися як між лікарем і конкретною особою, пацієнтом 
чи його родичем, за моделлю “лікар - не медик" (напр., розмова з пацієнтом (його родичами, друзями) перед медичним оглядом, під час медичного огляду із збиранням анамнезу, перед операцією, перед виписуванням з лікарні), так і мати масового адресата (виступ з метою пропаганди медичних знань, науково-популярна стаття, книжка, радіо-, телеінтерв'ю на медичну тему). Остання реалізується в досить широко представленому наборі таких “жанрів", як науково-популярні твори, словники, орієнтовані на дилетантів, а також численні інструкції 3 експлуатації численних приладів, інструкції із збирання предметів побуту, брошури з рекомендаціями для людей, що страждають від поширених хвороб, науково-популярні радіо- та телепередачі тощо. У цій моделі мову спілкування розглядають вже не як суто спеціальні термінологічні системи, а як неоднорідні комплекси, розшарування яких на горизонтальні пласти визначається такими параметрами, як комунікативна ситуація, партнер комунікації та комунікативні умови. Все сказане підтверджує думку про неоднорідність мови для спеціальних цілей.

Важливою складовою формування професійності медичного працівника є уміння впливати засобами мови на співрозмовника. Іншими словами, велику роль тут відіграє культура спілкування як сукупність правил мовленнєвої поведінки, втілених у системі стійких формул та висловів, прийнятих і запропонованих суспільством на тому чи іншому етапі його розвитку. Найвагомішою ознакою мовленнєвої культури є норма.

Унормованість є необхідною якістю літературного мовлення, без якого вона не змогла б виконати свою функцію як знаряддя розвитку суспільства, як засіб спілкування. Нормативність літературної мови - це природний ії стан, а норма-це усвідомлена реальність мови в її розвитку. Норма лише тоді є нормою, коли відображає об' єктивні закони розвитку мови.

Найширше теоретичне трактування норми літературної дав мовознавець М. М. Пилинський: 'Норма літературної мови - це реальний, історично зумовлений і порівняно стабільний мовний факт, що відповідає системі і нормі мови і становить єдину можливість або найкращий для даного конкретного випадку варіант, відібраний суспільством на певному етапі його розвитку із співвідносних фактів загальнонародної (національної) мови в процесі спілкування" [1].

Нормативний погляд на мову, за словами Г. М. Яворської, завжди виявляється як своєрідна діяльність, що полягає в створенні певних приписів (прескрипцій) щодо того, які мовні норми треба вва- жати правильними (літературними, прийнятними тощо), а які помилковими [2].

Норми надають мові характеру впорядкованості й загальної обов'язковості. Літературна норма мови це ознаки, правила літературного мовлення, яке є зразком писемної і усної форм спілкування. "Літературна норма використовується як основа регламентації, упорядкування та уніфікації загальнонародної мови і впроваджується суспільством у масове користування через систему освіти, культури, засобів масової комунікації ..." [3].

Відомо, що належний рівень культури мовлення передбачає свідоме дотримання встановлених норм літературної мови, цілеспрямоване й майстерне використання мовно-виражальних засобів залежно від мети та обставин спілкування, а також уникнення в мовній практиці жаргонної лексики, суржикових форм, слів-паразитів, діалектизмів, невмотивованих запозичень тощо. Відхилення від норм на різних мовних рівнях спричиняють типові помилки, які знижують культуру мовлення фахівця.

Пильної уваги потребують норми наголошення, які достатньо часто порушуються у професійному спілкуванні: камфора замість нормативного камфора; ортопедія, логопедія замість літературних ортопедія, логопедія; кишка, сеча, щииці, залоза, де словник рекомендує наголошення на першому складі: кишка, сеча, шүипџі, залоза. Слід пам'ятати й про акцентне варіювання, яке досить поширене в медичній термінології: ядуха, речовина, голосова щілина, ліжковий режим, простий герпес. Серед чинників, що зумовлюють виникнення паралельних наголосів у термінологічній лексиці, виділяють особливості внутрішньої структури слова, дію аналогіi, а також специфіку функціонування наголосу в усному мовленні.

В усному і писемному спілкуванні медичних працівників часто спостерігаємо надмірне вживання іншомовної термінології, яке в цілому не порушує лексичної норми, але подекуди не відповідає таким ознакам культури мови, як доречність або ясність. Про дбайливе ставлення до лексичного багатства рідної мови свідчать слова щзеплення замість вакцинація, вада замість дефект, природний замість натуральний, отруйний замість токсичний, пересадка замість трансплантаџія, кровотворення замість гемопоез, крововилив замість геморагія, грудний замість торакальний, мозковий замість церебральний, невідкладний замість екстрений тощо.

Критерієм відбору для вживання слів іншомовного походження має бути семантична і стилістична 
необхідність їх застосування. П. Селігей переконує, що українська термінологія, зокрема і медична, в добу глобалізації повинна збагачуватися насамперед із першоджерел, варто переймати не англіцизми, а досвід англійської та інших мов творити і закріплювати в ужитку власні слова. Перенасичення запозиченнями у термінології зовсім не сприяє ії̈ розвитку. "Самоусунувшись од власного термінотворення й ставши покірним споживачем чужих слів, ми, по суті, ставимо хрест на тих скарбах, які наша мова нагромаджувала століттями" [4].

Метою кожного носія мови є досягнення такої усної та писемної форми спілкування, яка б найповніше,

\section{Література}

1. Яворська Г. Лінгвістична свідомість і мовні норми /

Г. Яворська // Урок української. - 2001. - № 5. - С. 10.

2. Пилинський М. Мовна норма і стиль / М. Пилинський.

-К. : Наукова думка, 1976. - С. 98.

3. Мацько Л. І. Стилістика української мови : підручник / Л. І. Мацько, О. М. Сидоренко, О. М. Мацько ; за ред. Л. І. Мацько. -К. : Вища школа, 2003. -С. 170. найточніше передавала зміст думки, спираючись на невичерпні джерела рідної мови.

Висновок. Опанування норм сприяє підвищенню культури мови, а висока мовна культура є свідченням культури думки. Дотримання норм сучасної літературної мови є обов'язковою умовою повноцінної, якісної діяльності фахівця-медика; їхнє порушення відображає низький рівень мовної компетенції. Тому, як зазначає М. І. Лісовий, "Професійне мовлення ... медичних працівників - це володіння нормами літературної мови, фаховою термінологією і стандартизованими мовленнєвими конструкціями медичної галузі, здатність використовувати мовні засоби відповідно до мети й ситуації спілкування" [5].

4. Селігей П. Чужого навчаємося, а свого цураємося... / П. Селігей // Дивослово. -2008. - № 7.-С. 36-40.

5. Лісовий М. І. Формування професійного мовлення майбутніх медичних працівників у вищих медичних навчальних закладах : автореф. дис. на здобуття наук. ступеня канд. пед. наук : спец. 13.00.04 / М. І. Лісовий; Вінницький державний педагогічний ун-т ім. М. Коцюбинського. Вінниця, 2006.-С. 5. 